\title{
POULTRY LITTER AND SWINE COMPOST AS NUTRIENTS SOURCES IN MILLET
}

\author{
CAMA DE AVES E COMPOSTO DE SUÍNOS COMO FONTE DE \\ NUTRIENTES NA CULTURA DO PAINÇO
}

\begin{abstract}
Claudir José BASSO ${ }^{1}$; Dionei Schmidt MURARO² Eduardo GIROTTO $^{3}$; Diecson Ruy Orsolin da SILVA ${ }^{1}$; Alieze Nascimento da SILVA ${ }^{4}$

1. Professor, Doutor Universidade Federal de Santa Maria - UFSM, Campus de Frederico Westphalen, RS, Brasil. claudirbasso@gmail.com; 2. Estudante de graduação em Agronomia, UFSM, Campus de Frederico Westphalen, RS, Brasil; 3. Doutor, Professor, Instituto Federal de Educação Ciência e Tecnologia, Bento Gonçalves, RS, Brasil; 4. Mestranda do Programa de Pós Graduação em Agronomia: Agricultura e Ambiente, Universidade Federal de Santa Maria - UFSM, Campus de Frederico Westphalen, RS, Brasil
\end{abstract}

\begin{abstract}
Poultry and pork farming are typical activities of small farms in southern Brazil. This production plays an important social and economic role in many of these areas as it is often the main income source. The swine compost has emerged as an alternative to reduce the volume of swine wastewater, which is transformed into a residue that can be easily transported and applied with less environment prejudice. However, there is no information in literature regarding the use of this compound as a source of nitrogen in grain crops. Therefore, the aim of this study was to evaluate poultry litter and swine compost as organic sources of nitrogen for the millet crop. The experiment was conducted in the years of 2013 and 2014 in southern Brazil, in no-tillage systems in a Hapludox soil. The treatments were: control (without nitrogen); poultry litter (PL), swine compost (SC) and mineral fertilization (NPK). The use of poultry litter resulted in better averages for almost all evaluated variables. Although the swine compost did not express results as good as the crop treated with poultry litter, the crop in which the swine compound was applied presented better results for some plant parameters than the chemical fertilizer treatment, which shows that these two residues can be viable alternatives for nitrogen fertilization in millet cultivations.
\end{abstract}

KEYWORDS: Organic residues. Mineral nutrition. Production components. Grain yield.

\section{INTRODUCTION}

Millet (Panicum miliaceum L.) is one of the oldest cultivated plants in the world, along with other grains such as wheat and barley (LU et al. 2009). This grain has been used in mixtures for feeding birds and currently it is also used as human food in developing countries (SARUHAN et al., 2011). Millet crops are known for their tolerance to drought and the low water volume needed for their development (HEMADI et al., 2011, ACKO et al., 2012).

Compared to other traditional crops such as soybeans and corn, millet (Panicum miliaceum L.) is a lesser-known culture and studies regarding this crop are still uncommon. In the state of Rio Grande do Sul, Brazil, millet has drawn the growers attention, as an alternative to crop rotation with wheat crops during fall/winter due to its short cycle, allowing the soybean seeding period with in the culture's recommended cycle (BASSO et al., 2015).

In southern Brazil, poultry and swine farming are two important activities that are generally seen on small farms. Among these activities, the swine production concerns most the environmental entities due to the intense production and the generation of a large waste volume in small production units, sometimes in limited areas. Therefore, swine compost emerges as a good alternative to increase the number of animals in the production unit without needing a large area to residue accumulation.

In the process of composting, the swine slurry is pumped from the reservoir to a covered place where it is mixed withsawdust substrate, which due to its high absorption capacity, reduces significantly the pig slurry volume (BARRENA et al., 2001) as well as the number of pathogenic microorganisms, presenting high agronomic value (BUSTAMANTE et al., 2013).

The use of poultry litter (BOLAN et al. 2010; MUSA et al. 2012) and swine slurry (CERETTA ET AL. 2005; SÀNCHEZ; GONZÁLEZ 2005; SEIDEL et al. 2010, PINTO et al. 2014) as a source of nitrogen in major grain crops such as corn and wheat is already well documented in the literature. Due to the high nitrogen content in swine manure and the high demand of $\mathrm{N}$ by grasses, these plants presents, in most cases, linear and positive responses to the manure application (LYIMO et al., 2012). 
In both the poultry littler and the swine compost, most of the $\mathrm{N}$ present is in organic form so it may not be available to the plants during the growing periods (CREW; PEOPLES, 2005; HARTZ; JOHNSTONE, 2006), fact that is observed mainly in short cycle crops, such as millet. The assumption of this study is that millet responds positively to application of organic compost as a nitrogen source. Therefore, the aim of this study was to evaluate poultry litter and swine compost as organic sources of nitrogen for millet.

\section{MATERIAL AND METHODS}

This study was conducted in 2013 and 2014 in the experimental area of the Federal University of
Santa Maria, Frederico Westphalen campus at the Northwest region of Rio Grande do Sul, southern Brazil. The geographic coordinates of the area are $27^{\circ} 23$ 'S and $5325^{\prime} \mathrm{W}$ at an altitude of 566 meters. The climate is a subtropical humid (CFA) according to Koppen's classification (MORENO 1961). The meteorological data for maximum and minimum air temperatures and daily precipitation were collected by an automatic weather station located at a distance of $1200 \mathrm{~m}$ from the experimental area. The meteorological data was recorded electronically at 1 minute intervals and the values have been integrated into daily data (Figure 1).

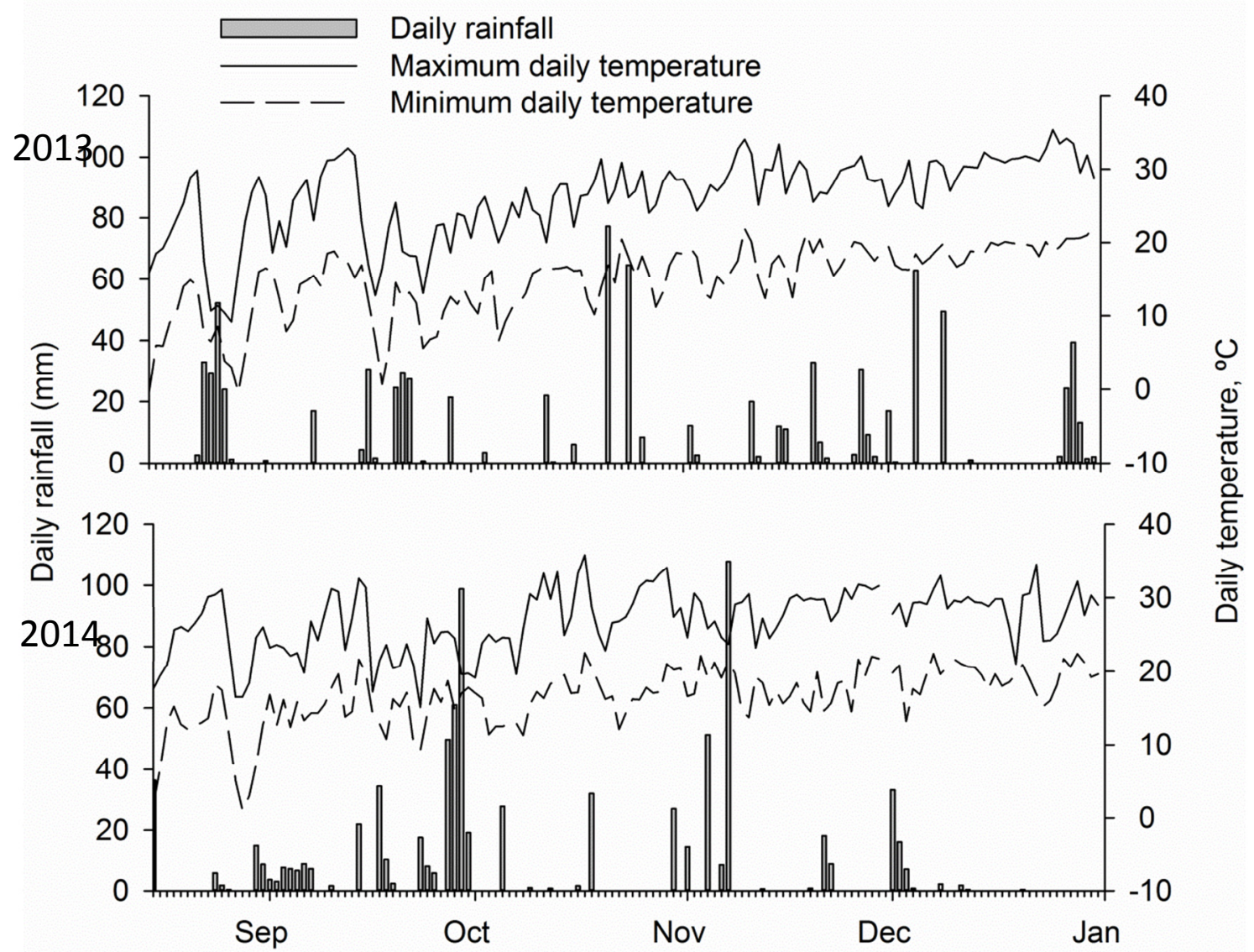

Figure 1. Average daily temperatures and daily rainfall during the experiment conduction. The rainfall data was obtained from a meteorological station in Frederico Westphalen, RS, Brazil.

The soil is classified as a typical sandy clay loam soil (EMBRAPA 2013) with a clay texture and the area was cultivated under a no-tillage system for more than 10 years, with soybean and corn crops in the summer and wheat and oat during winter. The experiment was conducted in one area in 2013 and in another area (next to the first one) during the 2014 crop year, aiming to avoid residual and cumulative manure effects in the soil.
During the experiment implementation, soil samples were collected in the layer from 0.00 to $0.20 \mathrm{~m}$ in both years, with the following characteristics: $\mathrm{pH}$ in $\mathrm{H}_{2} \mathrm{O}$ (1:1) 4.6; SMP index 5.1; clay $650 \mathrm{~g} \mathrm{~kg}^{-1}$; organic matter $2.7 \mathrm{~g} \mathrm{~kg}^{-1}$; P-mehlich $7.2 \mathrm{mg} \mathrm{dm}^{-3}$; potassium $137 \mathrm{mg} \mathrm{dm}^{-3}$; calcium 2.1 $\mathrm{cmol}_{\mathrm{c}} \mathrm{dm}^{-3}$; magnesium $1.2 \mathrm{cmol}_{\mathrm{c}} \mathrm{dm}^{-3} ; \mathrm{H}+\mathrm{Al} 8.0$ $\mathrm{cmol}_{\mathrm{c}} \mathrm{dm}^{-3}$; $\mathrm{Al} 2.1 \mathrm{cmol}_{\mathrm{c}} \mathrm{dm}^{-3}$; CTC $11.6 \mathrm{cmol}_{\mathrm{c}} \mathrm{dm}^{-3}$; and CEC bases and $\mathrm{Al}$ of 31.3 and $36.5 \%$, 
respectively. Area 2 (year of 2014): $\mathrm{pH}$ in $\mathrm{H}_{2} \mathrm{O}$ (1:1) 5.0, SMP index 5.4, clay $678 \mathrm{~g} \mathrm{~kg}^{-1}$, organic matter $3.0 \mathrm{~g} \mathrm{~kg}^{-1}$, P-mehlich $6.9 \mathrm{mg} \mathrm{dm}^{-3}$, potassium 219 $\mathrm{mg} \mathrm{dm}$, calcium $3.1 \mathrm{cmol}_{\mathrm{c}} \mathrm{dm}^{-3}$, magnesium 2.4 $\mathrm{cmol}_{\mathrm{C}} \mathrm{dm}^{-3}, \mathrm{H}+\mathrm{Al} 6.1 \mathrm{cmol}_{\mathrm{c}} \mathrm{dm}^{-3}, \mathrm{Al} 0.5 \mathrm{cmol}_{\mathrm{c}} \mathrm{dm}^{-3}$, CEC $12.2 \mathrm{cmol}_{\mathrm{C}} \mathrm{dm}^{-3}$, and CTC bases and $\mathrm{Al}$ of 49.8 and $7.6 \%$, respectively. Six months before the experiment, the soil $\mathrm{pH}$ was corrected with the application of lime in order to raise the $\mathrm{pH}$ to 6.0 following the recommendations of Soil Chemistry and Fertility Commission - CQFS-RS/SC - 2004).
During both years, the experiment was conducted in a randomized block design with four replications, where each plot had $4.0 \times 3.6 \mathrm{~m}$ with total area of $14.4 \mathrm{~m}^{2}$. The following treatments were studied: control (no fertilizer), poultry litter (PL), swine compound (SC), and mineral fertilization (MF). The application of PL and SC was carried out manually, immediately after the seeding process during both years, in order to supply the crop's nitrogen demand. Some characteristics of the two residues are shown in Table 1.

Table 1. Chemical characteristics of the organic carbon source $(\mathrm{C})$, nitrogen $(\mathrm{N})$, phosphorus $(\mathrm{P})$, potassium $(\mathrm{K})$, calcium $(\mathrm{Ca})$ and magnesium $(\mathrm{Mg})$, applied through the millet cultivation with poultry litter and swine compost treatments. Frederico Westphalen, RS. 2015.

\begin{tabular}{|c|c|c|c|c|c|c|c|}
\hline & $\mathrm{C}$ & $\mathrm{N}$ & $\mathrm{P}$ & K & $\mathrm{Ca}$ & $\mathrm{Mg}$ & $\mathrm{pH}$ \\
\hline Poultry litter & 29.8 & 2.94 & 0.40 & 2.47 & 1.78 & 0.56 & 7.7 \\
\hline Swine compound & 19.9 & 3.48 & 1.47 & 3.46 & 3.68 & 1.35 & 6.8 \\
\hline
\end{tabular}

The mineral fertilizer $\mathrm{N}$ was manually applied on soil surface during the seeding stage, as urea. The $\mathrm{N}$ amount for millet was calculated following the CQFS-RS/CS (2004) recommendations, and based on soil analysis. The crops under $\mathrm{SC}$ and $\mathrm{PL}$ treatment received $\mathrm{P}_{2} \mathrm{O}_{5}$ supplements in the form of a single superphosphate, and $\mathrm{K}_{2} \mathrm{O}$ in the form of potassium chloride to balance these nutrients amounts applied in the treatment with mineral fertilizer.

The experiment was conducted under a notillage system on the remnants of a soybean cultivation (Glycine max), which remained in fallow for about three months. For the experimental setup, the area was desiccated with glyphosate $\left(3.51 \mathrm{ha}^{-1}\right)$ and the millet seeding was performed manually on 09/14/2013 and 08/22/2014, using the cultivar AL Tibagi, spaced $0.45 \mathrm{~m}$ between rows and with 120 seeds per meter. The emergence occurred about 10 days after seeding for both years, with a cycle time of 87 and 93 days during the 2013 and 2014 crop years, respectively.

The following analyses were performed for millet: Dry matter: the full blooming area of 0.25 $\mathrm{m}^{2}$ was sampled and dried at a temperature of $65^{\circ}$ Cuntil constant weight; Plant height: measured from the ground surface to the top of the main stem panicle, performed in 10 random plants within each plot area using the average of the evaluation; Stem diameter: determined above the first internode using a digital caliper; Panicle length: obtained by averaging the distance between the insertion of the first branch of the rachis and the upper end of the panicles in 10 random plants within the useful area of each plot; Number of grains per panicle: obtained by counting the number of grains in three panicles randomly harvested in each parcel area; Thousand grain mass: sampling randomly and weighing five samples of 1000 seeds of each crop, correcting the values to $13 \%$ of moisture; Grain yield: evaluated by manual harvesting of the four central lines, discarding $0.3 \mathrm{~m}$ from each end with a total area of $2.7 \mathrm{~m}^{2}$. The seeding was performed with a trailed equipment and the grain weight corrected to $13 \%$ of moisture.

The results were submitted to variance analysis and when variables showed significance, the means were compared by a Tukey's test at 1.0 and $5.0 \%$ of error probability. For these analyses, the Statistical Analysis System - SAS 8.0 software (SAS Inc, Cary, USA) was used.

\section{RESULTS AND DISCUSSION}

There was no difference regarding the dry matter production of millet in 2013 according to the use of different nitrogen sources, but the use of poultry litter $\left(5424 \mathrm{~kg} \mathrm{ha}^{-1}\right)$ resulted in a better performance when compared to control (without $\mathrm{N}$ application), with an increase of $1429 \mathrm{~kg} \mathrm{ha}^{-1}$, or $35.7 \%$ (Table 2).For the 2014 crop year, the highest production of millet's dry matter was observed with poultry litter treatment (3918 kg ha-1), presenting an increase of $1908 \mathrm{~kg} \mathrm{ha}^{-1}$ when compared to control treatment; in other words, an increase of $94.8 \%$, but with no significant differences between the evaluated nutrients sources. 
Table 2. Shoot dry matter production and nitrogen accumulation in millet according to the use of different nitrogen sources. Frederico Westphalen - RS. 2015.

\begin{tabular}{lll} 
& \multicolumn{2}{c}{ Year } \\
\cline { 2 - 3 } Treatments & 2013 & 2014
\end{tabular}

\begin{tabular}{|c|c|c|c|c|c|c|c|}
\hline & $\begin{array}{l}\text { Dry me } \\
(\mathrm{kg} \mathrm{h}: \\
\end{array}$ & & $\begin{array}{l}\mathrm{N} \text { accumulation } \\
\left(\mathrm{kg} \mathrm{ha}^{-1}\right)\end{array}$ & $\begin{array}{l}\text { Dry matter } \\
\left(\mathrm{kg} \mathrm{ha}^{-1}\right) \\
\end{array}$ & & $\begin{array}{l}\text { N accumulat } \\
\left(\mathrm{kg} \mathrm{ha}^{-1}\right) \\
\end{array}$ & \\
\hline Control (no N) & 3995 & $a^{*}$ & $110.86 \mathrm{~b}$ & 2010 & $\mathrm{~b}$ & 60.03 & $\mathrm{~b}$ \\
\hline Poultry littler & 5424 & $\mathrm{a}$ & 156.89 a & 3918 & $\mathrm{a}$ & 102.09 & $\mathrm{a}$ \\
\hline Swine compost & 4406 & $a b$ & $120.08 \mathrm{ab}$ & 3319 & $\mathrm{a}$ & 87.15 & $\mathrm{ab}$ \\
\hline Chemical fertilizer & 4605 & $a b$ & $118.00 \mathrm{ab}$ & 3535 & $\mathrm{a}$ & 83.28 & $a b$ \\
\hline $\mathrm{CV}-\%$ & 11. & & 12.6 & 11.23 & & 13.7 & \\
\hline
\end{tabular}

*Means followed by the same letter do not differ by Tukey's test at $5 \%$ of probability.

When compared to chemical fertilizers, even with no significant difference, the poultry litter increased the millet dry matter production for the years 2013 and 2014 by $17.7 \%$ and $10.8 \%$, respectively. By studying different sources of nitrogen in the cut-off frequency in millet's forage quality, Mohammed et al. (2015) also observed superiority with the use of poultry litter by $23 \%$, compared to the use of chemical fertilization. A slower and gradual mineralization with higher nitrogen release regarding the demands of the crop may explain the difference between poultry litter in relation to chemical fertilizer. According to Sistani et al. (2008), this improved response to the poultry litter may also be associated with rapid mineralization where their study observed a mineralization of $62 \%$ of the total organic $\mathrm{N}$ over a 90 days period.

For the two years of experiment, although the treatments did not lead to significantly different results, the use of chemical fertilizer presented better results than the use of swine compost. This fact are not in accordance to the observed by Giacomini \& Aita (2008), which when evaluating swine slurry, poultry litter and urea in corn crops, observed that poultry litter's presented a lower immediate effect as a source of $\mathrm{N}$ when compared to swine slurry and urea. The apparent recovery of $\mathrm{N}$ for corn from poultry litter and swine slurry in the experiment of these authors was 10.9 and $22.1 \%$, respectively. For the poultry litter, it was observed a decrease of the ammonia based nitrogen and, on the other hand, an increase of $\mathrm{N}$ in the nitrate form, as observed by Sistani et al. (2008). Azeez \& Averbeke (2010), observed a rapid mineralization of organic $\mathrm{N}$ by soil microorganisms; the $\mathrm{N}$ in ammonia form is a result of this process of the nitrification in the soil, which was also observed by Aita et al. (2013) in their study. Agehara \& Warncke (2005) observed that during the incubation process for poultry litter in two distinct phases, a fast mineralization of organic $\mathrm{N}$ occurred in the first two weeks, followed by a slow phase with lower increased rate. This rapid mineralization of the poultry litter in the initial phase of millet development is important due to the fact that many plant and productivity parameters are defined in the initial phase of a crop development.

The accumulation of $\mathrm{N}$ in the aerial parts of millet for the two-year study was higher in the treatment with poultry litter when compared to control (without $\mathrm{N}$ ), but there was no significant difference among the nitrogen sources (Table 2).Comparing to the control, the poultry litter increased the $\mathrm{N}$ accumulation in the millet aerial part by $41.5 \%$ and $70.1 \%$ during 2013 and 2014, respectively. The use of swine compost and chemical fertilization resulted in no statistic difference from the control. The highest $\mathrm{N}$ accumulation in millet shoot with application of poultry litter can be associated with the fact that most part of the organic $\mathrm{N}$ from these residues suffer gradual mineralization, releasing during the crop cycle, in accordance to Giacomini et al. (2013), when studying the $\mathrm{N}$ recovery from corn and beans, with the application of swine farming residue. Evaluating the swine composting and fresh swine manure on $\mathrm{N}$ accumulation in corn, Loecke et al. (2012) observed a higher accumulation during two years of study with the compost application, even when the $\mathrm{N}$ availability in the plant need was not been well elucidated.

For plant height (Table 3), regardless the year of cultivation, poultry litter increased plant height as compared to control but with no differences according to the $\mathrm{N}$ source, similar to the pattern observed for dry matter contents. According 
to Ayub et al. (2009), this variable may be the main factor related to the increase in dry matter production. Comparing the treatment without $\mathrm{N}$ addition, during 2013 and 2014anincrease of 9.0 and $11.0 \mathrm{~cm}$ were observed with the use of poultry litter, regarding the plant height variable. In 2014, no significant differences in plant height among the different $\mathrm{N}$ sources were observed, being all of them higher than the control.

The increase in plant height with the application of $\mathrm{N}$ sources was expected due to the higher supply of N. Soratto et al. (2007) observed that regardless of the time of $\mathrm{N}$ application, this practice increased the plant height, and this relation was linear with $\mathrm{N}$ application during 14 days after emergence (tillering) and quadratic for 28 days after emergence. Evaluating the time and dose of $\mathrm{N}$ application in the millet, Basso et al. (2015) observed an increase in plant height with increasing $\mathrm{N}$ doses and with the application of $30 \%$ of the recommended $\mathrm{N}$ amount at seeding, being the remaining amount applied on soil surface. Evaluating different organic residues to supply the nutrients in the barley crop, Ofosu \& Leitch (2009) also observed a higher plant height with the use of organic residue.

Regarding the stem diameter (Table 3), millet responded significantly to nitrogen application when compared to control (without $\mathrm{N}$ ), but there was no response according to the evaluated $\mathrm{N}$ sources during the two studied crop years. This positive response in stem diameter with application of $\mathrm{N}$, regardless the source, are in accordance to the results observed by other authors (MENALLED et al., 2005; SORATTO et al, 2010).

There was no significant difference among the treatments for a thousand millet seeds during the evaluated years, although it is possible to observe a trend to present higher values in the treatments involving the application of organic residue (Table 4).

Table 3. Plant height and stem diameter of millet under different nitrogen sources for the 2013 and 2014 crop years. Frederico Westphalen-RS. 2015.

\begin{tabular}{|c|c|c|c|c|c|c|c|c|}
\hline \multirow{3}{*}{ Treatments } & \multicolumn{8}{|c|}{ Year } \\
\hline & \multicolumn{4}{|c|}{2013} & \multicolumn{4}{|c|}{2014} \\
\hline & \multicolumn{2}{|c|}{$\begin{array}{l}\text { Plant height } \\
(\mathrm{cm})\end{array}$} & \multicolumn{2}{|c|}{$\begin{array}{l}\text { Stem diameter } \\
(\mathrm{mm})\end{array}$} & \multicolumn{2}{|c|}{$\begin{array}{l}\text { Plant height } \\
(\mathrm{cm})\end{array}$} & \multicolumn{2}{|c|}{$\begin{array}{c}\text { Stem } \\
\text { diameter }(\mathrm{mm})\end{array}$} \\
\hline Control (without N) & 164 & $b^{*}$ & 3.69 & B & 81 & $\mathrm{~b}$ & 3.20 & b \\
\hline Poultry litter & 173 & $\mathrm{a}$ & 4.52 & A & 111 & $\mathrm{a}$ & 4.50 & $\mathrm{a}$ \\
\hline Swine compost & 167 & $a b$ & 4.45 & A & 96 & $\mathrm{a}$ & 4.42 & $\mathrm{a}$ \\
\hline Chemical fertilizer & 166 & $\mathrm{ab}$ & 4.37 & $\mathrm{a}$ & 101 & $\mathrm{a}$ & 4.20 & $\mathrm{a}$ \\
\hline CV - \% & 2.0 & & 6.5 & & 9.14 & & 7.71 & \\
\hline
\end{tabular}

*Means followed by the same letter are not different according to Tukey's test at $5 \%$ of probability.

Table 4. Thousand seeds weight and yield (Y) of millet grains submitted to different nitrogen sources. Frederico Westphalen - RS. 2015.

\begin{tabular}{|c|c|c|c|c|}
\hline \multirow{3}{*}{ Treatments } & \multicolumn{4}{|c|}{ Year } \\
\hline & \multicolumn{2}{|c|}{2013} & \multicolumn{2}{|c|}{2014} \\
\hline & $\begin{array}{l}\text { Thousand seeds } \\
\text { weight }(\mathrm{g})\end{array}$ & $\begin{array}{l}\text { Grain yield } \\
\left(\mathrm{Kg} \mathrm{ha}^{-1}\right)\end{array}$ & $\begin{array}{l}\text { Thousand grains } \\
\text { weight }(\mathrm{g})\end{array}$ & $\begin{array}{c}\text { Grain yield } \\
\left(\mathrm{Kg} \mathrm{ha}^{-1}\right)\end{array}$ \\
\hline Control & $3.62 \mathrm{a}$ & $2386 \mathrm{c}^{*}$ & $2.79 \mathrm{a}$ & $1364 \mathrm{~b}$ \\
\hline Poultry litter & $4.46 \mathrm{a}$ & $4528 \mathrm{a}$ & $3.88 \mathrm{a}$ & 2954 a \\
\hline Swine compost & $4.24 \mathrm{a}$ & $3902 \mathrm{~b}$ & $3.81 \mathrm{a}$ & $1956 \mathrm{~b}$ \\
\hline Chemical fertilizer & $3.64 \mathrm{a}$ & $2921 \mathrm{c}$ & $3.71 \mathrm{a}$ & $1843 \mathrm{~b}$ \\
\hline $\mathrm{CV}-\%$ & 12.74 & 7.29 & 15.90 & 18.47 \\
\hline
\end{tabular}

*Means followed by the same letter are not different according to Tukey's test at 5\% of probability. 
For grain yield during the two studied years, a higher yield was observed with application of poultry litter of 4528 and $2954 \mathrm{~kg} \mathrm{ha}^{-1}$, for the years of 2013 and 2014, respectively. This yield represents an increase of $89.7 \%$ and $116.4 \%$ for 2013 and 2014, respectively, when compared to control (no $\mathrm{N}$ ). The use of this residue as $\mathrm{N}$ source for millet and compared to the chemical fertilization resulted in an increase in millet grain yield with the use of poultry litter of $1607 \mathrm{~kg} \mathrm{ha}^{-1}(55.0 \%)$ and $1110 \mathrm{~kg} \mathrm{ha}^{-1}(60.3 \%)$, respectively, for the years of 2013 and 2014.The same trend of an increase in grain yield was observed with the use of the swine compost, showing that these two residues can completely replace the nitrogen fertilization in millet cultivations, being also important due to the cycling of this nutrient during the unit production.

By studying the relation of swine compost and grain yield of some crops such as corn (Loecke et al., 2004; Lymo et al. 2012) and wheat (Muhammad et al. 2008), the cited authors also observed an increase in grain yield. For these authors, a slow and gradual release of $\mathrm{N}$ may be the reason for this increased yield with the use of residues, which may also be associated with an increased synchronization between the availability of the nutrient and the plant demand (NEVENS; REHEUL 2003).

\section{CONCLUSIONS}

Among the studied organic residues, the application of poultry litter resulted in the most positive impact for almost all evaluated variables.

The use of swine compost resulted in inferior results when compared to the use of the poultry litter, but for some plant variables, the studied options resulted in better response when compared to the use of chemical fertilizers.

Thus, the two evaluated residues from animal production can fully replace the nitrogen fertilization in millet. Even being known as a rustic crop, the millet responded positively to nitrogen fertilization.

RESUMO: A criação de aves e suínos são atividades típicas de pequenas propriedades na região sul do Brasil e representam um papel importante sob o ponto de vista social e econômico, pois em muitas dessas unidades são as principais geradoras de receita. O composto de suínos tem surgido como alternativa que reduz o volume de dejeto liquido de suínos, e o transforma em um resíduo de fácil transporte e aplicação e menor impactante ao meio ambiente. Porém, não existe na literatura informações quanto a utilização desse composto de suínos como fonte de nitrogênio em culturas produtores de grãos. Por isso, o objetivo deste trabalho foi avaliar a cama de frango e o composto de suínos como fontes orgânicas de nitrogênio na cultura do painço. O trabalho foi conduzido nos anos de 2013 e 2014 na região Sul do Brasil, em sistema plantio direto em um Hapludox soil. Os tratamentos foram os seguintes: Testemunha (sem nitrogênio); Cama de aves (CA), Composto de suínos (CS) e Adubação mineral (NPK). A cama de aves foi a que mais impactou positivamente para quase todas as variáveis analisadas. Já o composto de suínos foi inferior a cama de aves, porém para alguns parâmetros de planta igual ou superior a própria adubação química mostrando que esse dois resíduos podem substituir totalmente a adubação mineral nitrogenada na cultua do painço.

grãos.

PALAVRAS-CHAVES: Resíduos orgânicos. Nutrição mineral. Componentes da produção. Produtividade de

\section{REFERENCES}

ACKO, D. K.; SANTAVEC, I.; CYETKO, M. Production of common millet (Panicum miliaceum L.) in Slovenia and effect of sowing time and sowing density on grain yield of the "soncek" cultivar. Journal of Food, Agriculture \& Environment, Finland, v. 10, n. 1, p. 417-422, 2012.

AGEHARA, S.; WARNCKE, D. D. Soil moisture and temperature effects on nitrogen release from organic nitrogen sources. Soil Science Society America Journal, Madison, v. 69, p. 1844-1855, 2005.

https://doi.org/10.2136/sssaj2004.0361

AITA, C.; BALEM, A.; PUJOL, S.B.; SCHIRMANN, J.; GONZATTO, R.; GIACOMINI, D. A.; VARGAS, P. V.; GIACOMINI, S. Redução na velocidade da nitrificação no solo após aplicação de cama de aviário com dicianodiamida. Ciência Rural, Santa Maria, v. 43, p. 1387-1392, 2013. https://doi.org/10.1590/S010384782013005000102 
AZEEZ, J. O.; VANAVERBEKE, W. Nitrogen mineralization potential of three animal manures applied on a sandy clay loam soil. Bioresour Technology, Taiwan v. 101, n. 14, p. 5645-5651, 2010.

https://doi.org/10.1016/j.biortech.2010.01.119

AYUB, M.; NADEEM, M. A.; TAHI, M.; IRAHIM, M.; ASLAM, M. Effect of nitrogen application and harvesting intervals on forage yield and quality of pearl millet (Pennisetum americanum L.). Pakistan Journal of Life and Social Science, Pakistan, v. 7, n. 2, p. 185-189, 2009.

BARRENA, R.; TURET, J.; BUSQUETS, A.; FARRES, M.; FONT, X.; SANCHEZ, A. Respirometric screening of several types of manure and mixtures intended for composting. Bioresour Technology, Taiwan, $v$. 102, n. 2, p. 1367-1377, 2011. https://doi.org/10.1016/j.biortech.2010.09.011

BASSO, C. J.; SOMAVILLA, L.; SANTI, A. L.; LAMEGO, F. P.; CARON, B. O.; MURARO, D. S.; PANSERA, E.; SILVA, R. F. Rates and application time of nitrogen in poroso millet. Bioscience Journal, Uberlandia, v. 31, n. 4, p. 1030-1036, 2015. https://doi.org/10.14393/BJ-v31n4a2015-26139

BOLAN, N. S.; SZOGI, A. A.; CHUASAVAYHI, T.; SESHADRI, B.; ROTHROCK, M, J.; PANNEERSELVAM, P. Uses and management of poultry litter. World's Poultry Science Journal, Cambridge, v. 66, n. 4, p. 673-698, 2010. https://doi.org/10.1017/S0043933910000656

BUSTAMANTE, M. A.; RESTREPO, A. P.; ALBURQUERQUE, J. A.; PEREZ-MURCIA, M. D.; PAREDES, C.; MORAL. R.; BERNAL, M. P. Recycling of anaerobic digestates by composting: effect of the bulking agent used. Journal of Cleaner Production, v. 47, p. 61-69, 2013. https://doi.org/10.1016/j.jclepro.2012.07.018

CERETTA, C. A.; BASSO, C. J.; PAVINATTO, O. S.; TRENTIN, E. E.; GIROTTO, E. Produtividade de grãos de milho, produção de matéria seca e acúmulo de nitrogênio, fósforo e potássio na rotação aveia preta/milho/nabo forrageiro com aplicação de dejeto líquido de suínos. Ciência Rural, Santa Maria, v. 35, n. 6, p. 1287-1295, 2005. https://doi.org/10.1590/S0103-84782005000600010

COMISSÃO DE QUÍMICA E FERTILIDADE DO SOLO (CQFS RS/SC). Manual de adubação e calagem para os estados do Rio Grande do Sul e Santa Catarina. 10.ed. Porto Alegre: Sociedade Brasileira de Ciência do Solo/Núcleo Regional Sul, 2004. 400p.

CREWS, T. E.; PEOPLES, M. B. Can the synchrony of nitrogen supply and the crop demand be improved in Legume and fertilizer-based agroecosystems A review, Nutrient Cycling in Agroecosystems, v. 72, n. 2, p. 101-120, 2005. https://doi.org/10.1007/s10705-004-6480-1

Empresa Brasileira De Pesquisa Agropecuária (Embrapa) (C) Centro Nacional de Pesquisa de Solos. Sistema brasileiro de classificação de solos. 3. ed. Rio de Janeiro

GIACOMINI, S.; AITA. C. Cama sobreposta e dejeto líquido de suínos como fonte de nitrogênio ao milho. Revista Brasileira de Ciência do Solo, Viçosa, v. 32, p. 95-205, 2008. https://doi.org/10.1590/S0100204X2013000200012

GIACOMINI, S. J., AITA, C.; PUJOL, S. B.; MIOLA, E. C. C. Transformações do nitrogênio no solo após adição de dejeto líquido e cama sobreposta de suínos. Pesquisa Agropecuária Brasileira, Brasília, v. 48, n. 2 , p. 211-219, 2013

HARTZ, T. K.; JOHNSTONE, P. R. Nitrogen availability from high-nitrogen containing organic fertilizers. Hort Technology, Purdue, v. 16, n. 1, p. 39-42, 2006.

HERMADI, K.; JAMEI, M.; HOUSEINI, F. Z. Climate change and its effect on agriculture water requirement in Khuzestan plain, Iran. Journal of Food, Agriculture \& Environment, Finland, v. 9, n. 1, p. 624-628, 2011. 
LOECKE, T. D.; LIEBMAN, M.; CAMBARDELLA, C. A.; RICHARDS, T. L. Corn growth responses to composted and fresh solid swine manure. Crop Science, Madison v. 44, n.1, p. 177-184, 2004.

https://doi.org/10.2135/cropsci2004.0177

https://doi.org/10.2135/cropsci2004.1770b

LOECKE, T. D.; CAMBARDELLA, C. A.; LIEBMAN,M. Synchrony of net nitrogen mineralization and maize nitrogen uptake following applications of composted and fresh swine manure in the Midwest U.S.

Nutrient Cycling in Agroecosystems, v. 93, n. 1, p. 65-74, 2012. https://doi.org/10.1007/s10705-012-9500-6

LU, H.; ZHANGA, J.; LIUB, K. B.; WUA. N.; LIC, Y.; ZHOUA, K.; MAOLIN, Y.; ZHANG, T.; ZHANGE, H.; YANG, X.; SHENE, L.; XUA, D.; LIA, Q. Earliest domestication of common millet (Panicummiliaceum) in East Asia extended to 10,000 years ago. Proceedings of the National Academy of Sciences, v. 106, n. 18, p. 7367-7372, 2009. https://doi.org/10.1073/pnas.0900158106

LYIMO, H. J. F.; PRATT, R. C.; MNYUKU, R. S. O. W. Composted cattle and poultry manures provide excellent fertility and improved management of gray leaf spot in maize. Field Crops Research, v. 126, p. 97103, 2012. https://doi.org/10.1016/j.fcr.2011.09.023

MOHAMMED, Y. A.; RAUM, W.; KAKANI, G.; ZHANG, Z.; TOYLOR, R.; DESTA, K. G.; MULLOK, J.; BUSHONG, J.; SUTRADHAR, A.; ALI, M. S.; REINERT, M. Nutrient sources and harvesting frequency on quality biomass production of switch grass (Panicum virgatum L.) for biofuel. Biomass and Bioenergy, v. 81, p. 242-248, 2015. https://doi.org/10.1016/j.biombioe.2015.06.027

MENALLED, F. D.; BUHLER, D. D.; LIEBMAN, M. Composted swine manure effects on germination and early growth of crop and weed species under greenhouse conditions. Weed Technology, v. 19, n. 4, p. 784789, 2005. https://doi.org/10.1614/WT-04-224.1

MORENO, J. A. Clima do Rio Grande do Sul. Secretaria da Agricultura, Porto Alegre, 1961.

IBRAHIM, M.; HASSAN, A.; IQBAL, M.; VALEEM, E. E. Response of wheat growth and yield to various levels of compost and organic manure. Pak. J. Bot. v. 40, n. 5, p. 2135-2141, 2008.

MUSA, I. W.; SAI'DU, L.; KALTUNGO, Y. B.; ABUBAKAR, B. U. WAKAWA, M. A. Poultry litter selection, management and utilization in Nigeria. Asian Journal of Poultry Science, Dubai, v. 6, n. 2, p. 4455, 2012. https://doi.org/10.3923/ajpsaj.2012.44.55

NEVENS, F.; REHEUL, D. The application of vegetable, fruit and garden waste (VFG) compost in addition to cattle slurry in a silage maize monoculture: nitrogen availability and use. Europe Journal of Agronomy, v. 19, n. 2, p. 189-203, 2003. https://doi.org/10.1016/S1161-0301(02)00036-9

OFOSU-ANIM, J.; LEITCH, M.; Relative efficacy of organic manures in spring barley (Hordeum vulgare L.) production. Australian Journal of Crop Science, v. 13, n. 1, p. 13-19, 2009.

PINTO, M. A. B.; FABBRIS, C.; BASSO, C. J.; SANTI, A. L.; GIROTTO, E. Aplicação de dejeto líquido de suínos e manejo do solo na sucessão aveia/milho. Pesquisa Agropecuária Tropical, Goiania, v. 44, n. 2, p. 205-212, 2014. https://doi.org/10.1590/S1983-40632014000200002

SÁNCHEZ, M.; GONZÁLEZ, J. L. The fertilizer value of pig slurry: I. Values depending on the type of operation. Bioresource Technology, v. 96, n. 10, p. 1117-1123, 2005.

https://doi.org/10.1016/j.biortech.2004.10.002

SARUHAN, V.; KUSVURAM, A.; BABAT, S. The effect of different humic acid fertilization on yield and yield components performances of common millet (Panicum miliaceum L.). Scientific Research and Essays, v. 6, n. 3, p. 663-669, 2011. 
SEIDEL, E. P.; JUNIOR, A. C. G.; VANIN, J. P.; STREY, L.; SSCWANTES, D.; NACKE, H. Aplicação de dejeto líquido de suínos na cultura do milho cultivado em sistema plantio direto. Acta Scientiarum.

Technology, Maringá, v. 32, n. 2, p. 113-117, 2010.

SORATTO, R. P.; CARDOSO, S. M.; SILVA, A. H.; COSTA, T. A. M.; PEREIRA, M. CARVALHO, L. A. Doses e épocas de aplicação de nitrogênio em cobertura na cultura do painço (Panicum miliaceum L.). Ciência e Agrotecnologia, Lavras, v.31, n. 6, p.1661-1667, 2007. https://doi.org/10.1590/S1806-66902010000400002

SORATTO, R. P.; PEREIRA, M.; COSTA, T. A. M.; LAMPERT, V. N. Fontes alternativas e doses de nitrogênio no milho safrinha em sucessão à soja. Revista Ciência Agronômica, Fortaleza, v. 41, n. 4, p. 511518, 2010.

SISTANI, K. R.; ADELI, A.; McGOWEN, S. L.; TEWOLDE, H.; BRINK, G.E. A. Laboratory and field evaluation of broiler litter nitrogen mineralization. Bioresource Technology, v. 99, n. 7, p. 2603-2611, 2008. https://doi.org/10.1016/j.biortech.2007.04.069 